\title{
Religious responses to the COVID-19 pandemic
}

DOI: https://doi.org/10.30664/ar.111498

Attribution 4.0 International (CC BY 4.0)

$\mathrm{T}$ he years 2020 and 2021 will be remembered as a time profoundly marked by the COVID-19 pandemic. We have all had to come to grips with the effects of this invisible global menace, which has left any number of visible traces behind in its wake, not only individually but also as members of the communities, whatever contours and foundations they may have, to which we belong. Religious communities in particular have attempted to adapt to, or in some cases resist, the strictures imposed by various forms of lockdown which have lasted for varying stretches of time, have created rituals intended to address the needs and concerns of their members, and have formulated explanations for the emergence of the pandemic in terms of their doctrinal systems. The first five articles in this issue of Approaching Religion explore such community-based ways of interpreting and dealing with the impact of the COVID-19 crisis.

The Issue OPEnS With A STUdy of Hindu responses to the pandemic written by Kathinka Frøystad. Her article highlights the multiplicity of responses that took shape as Hindus in various social positions attempted to respond to the COVID19 crisis. In some localities, for instance, temples were erected to a Corona goddess, prompting other sectors of Indian society to decry the perceived 'superstition' of doing so. The Indian government imposed a strict lockdown to curb the spread of the virus, but also used the pandemic as yet another occasion to promote its aim of privileging Hindu practices and lifestyles in a multireligious nation. Finally, the lockdown measures accentuated economic disparity in that more privileged religious communities could move their activities online. Frøystad notes that, despite the severity of the outbreak, continuity and conservatism prevailed and that most changes to religious practices were merely passing responses.

The next contribution, by Jonas Svensson, is a study concerning how a number of Islamic reactions to the COVID-19 crisis can be understood in terms of the cognitive science of religion. Svensson surveys four topics in particular: How do Muslim voices interpret the agency behind the pandemic (e.g. by attributing it to the wrath of God directed at a flawed humanity)? How do they justify such measures as closing mosques and banning communal Friday prayers? How do Muslim apologists argue for the superiority of their religion in the face of the worldwide spread of the contagion? Finally, how do discussions of the COVID-19 pandemic mesh with normative notions of ritual purity and ideas about how this state of purity risks being breached? Cases illustrating each of these issues show how Islamic responses can be 
understood as specific instances of cognitively based, cross-culturally shared ways of reasoning.

The need to radically restrict physical interaction has been a particular challenge for religious groups that value communal rituals. Giuseppina Addo is the author of the next article in this issue, one investigating how African Pentecostals in Italy a community whose gatherings are infused with vibrant sensory experiences - have adapted to the need to move their activities online. Building on the theoretical concept of affordances, that is, how people interpret, use, and interact with their environments, Addo shows how digital platforms have presented opportunities as well as challenges for participants accustomed to the rich musical tapestry, emotionally delivered sermons, and participatory elements such as shouts of 'Amen' and the rounds of applause characteristic of congregational gatherings which are held in physical settings.

The fourth article in this collection, by Benjamin E. Zeller, surveys a range of COVID responses that have arisen within new religious movements. New religions are remarkably diverse, and their ways of dealing with the pandemic have run the entire gamut from adhering to official guidelines for social distancing to actively resisting such measures. When these differences are viewed against the backdrop of the degree of alignment of the various movements with the values and norms of major social institutions, it turns out that there is no obvious overlap: movements that exist in considerable tension with the host society can thus insist that its members follow the guidelines of public health authorities. Zeller's article shows how a more fine-grained analysis of how movements rely on their pre-existing ideologies and how they orient themselves towards the social and cultural values of specific subgroups within the host society can help explain the diversity of responses.

In his contribution, Erik Östling focuses on one particular new religious movement, the Westboro Baptist Church. This group has been the focus of much media attention for its very vocal rejection of many of the values of its surrounding society, which has led to it being labelled a hate group. Its response to the COVID-19 crisis has been an extension of its basic theological commitments, including the belief that humanity exists in a state of total depravity and can only be saved through unmerited divine grace. In their view, the existence of same-sex intimate relations, and the increasing acceptance of them within mainstream society, is the ultimate sign of humanity's sinful nature, and the COVID19 crisis, when seen from this perspective, is just another tool God uses in order to punish humankind. Jubilantly celebrating the increasing death toll becomes, then, an additional way for the Westboro Baptist Church to proclaim its message in what has become its characteristically theatrical and deliberately shocking fashion.

Several articles on the reactions within specific religious milieus note how the pandemic has accelerated the spread of conspiracy theories and the scapegoating of a host of Others. Numerous reports in both academic publications and the media have also addressed the fact that large numbers of people may assert, for example, that COVID-19 is linked to $5 \mathrm{G}$ networks, or that the pandemic is actually a hoax perpetrated by various shadowy actors. In their contribution, Asbjørn Dyrendal and Knut Hestad investigate the link between conspiracy thinking about COVID-19 and other factors such as levels of trust in institutions and organizations, religiosity, and a general propensity for conspiratorial 
thinking. Among their findings is the fact that there is a strong correlation in their survey data between belief in COVID conspiracy theories and other forms of conspiracy thinking, but, contrary to widelyshared ideas, there is little correlation with the experience of living in a threatening and stressful situation, and no correlation with gender or age.

The final contribution to this collection, by Johan Höglund and Rebecca Duncan, highlights the fact that although the pandemic has - as the prefix pan-implies spanned the entire planet, different communities have themselves been affected very differently. The effects of the crisis have largely followed pre-existing global economic, racial, and gendered fault lines: already disenfranchised groups have been most severely disadvantaged by the pandemic. Their article argues that these disparities hence amount to a form of structural violence imposed by the capitalist world system. What is new about the current health crisis is that it has ultimately been caused by the same capitalist system, since, according to one proposed scenario, the virus jumped from animals to humans because large-scale deforestation has led to increased contact between species. Ultimately, both the crisis itself and its unequal impacts are effects of what some authors have called the Capitalocene age.

What the seven contributions to this issue illustrate is that although COVID19 is a global health crisis, the effects of, and responses to, the pandemic are divergent and often local. People's understandings of the issues involved and their ways of dealing with them depend on numerous factors, ranging from the ideological building blocks available within their community, via the cognitive mechanisms that can enhance conspiracy thinking or intensify the ritual avoidance of sources of (imagined) pollution, to factors such as economic disparity and the top-down effects of decisions made by powerful institutions and individuals. Although we live in a thoroughly globalized world where COVID-19 impacts everybody, we are clearly not all in the same boat.

\section{OLAV HAMMER and KAREN SWARTZ}

Guest editors

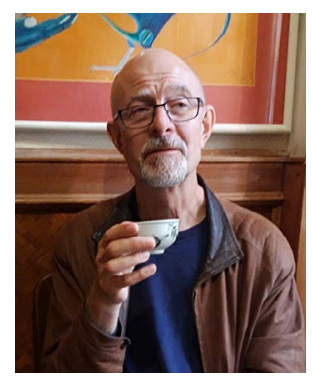

Olav Hammer is a professor in the study of religion at the University of Southern Denmark. He has specialized in 'alternative' forms of religion in the contemporary West and has published extensively on such subjects as New

Age religion, the theosophical current, Western esotericism, and alternative archaeology. He has in particular investigated the ways in which spokespersons for such religious currents interact with the dominant discourses of mainstream society: how do they defend their claims, how do sceptical outsiders view them, how do they react to the hegemonic position of the science, and how do adherents and detractors engage in polemics? He has published several monographs, edited numerous volumes, and has beside publications intended for an audience of academic peers also been engaged in disseminating his research to a broader readership.

Karen Swartz is adjunct lecturer in English linguistics and literature at Mid Sweden University and Western Norway University of Applied Sciences. Her primary field of research is the study of religions, and her area of focus is the history and development of the Anthroposophical Society. She is currently finalizing her doctoral thesis entitled Management Matters: Organizational Storytelling within the Anthroposophical Society in Sweden. Her work engages with organizational approaches to the 
study of religions, a topic on which she has also published other work. Besides her main focus on anthroposophy, she has a broader interest in untraditional forms of religiosity in the West and the ways in which these interact with popular culture. A product of this scholarly interest is a forthcoming volume on alternative archaeology, co-authored with Olav Hammer. 